\title{
Nilssonia hurum (Gray 1830) - Indian Peacock Softshell Turtle
}

\author{
Indraneil Das ${ }^{1}$, Dhruvajyoti Basu ${ }^{2}$, ANd Shailendra Singh ${ }^{3}$ \\ ${ }^{1}$ Institute of Biodiversity and Environmental Conservation, Universiti Malaysia Sarawak, \\ 94300 Kota Samarahan, Sarawak, Malaysia [idas@ibec.unimas.my]; \\ ${ }^{2}$ Katerniaghat Foundation, (R)1/737 Vikas Nagar, Lucknow 226022, Uttar Pradesh, India [dhrubasu@ rediffmail.com]; \\ ${ }^{3}$ Centre for Herpetology, Madras Crocodile Bank Trust, Post Bag 4, Mamallapuram 603 104, \\ Tamil Nadu,India [shailendra_mcbt@yahoo.com]
}

Summary. - The Indian peacock softshell turtle, Nilssonia hurum (Family Trionychidae), is a relatively abundant large riverine species that is found in rivers and reservoirs. The species attains a rather large size (carapace length to $60 \mathrm{~cm}$ ). It is distributed over eastern Pakistan, northern and central India, Bangladesh, and Nepal. The species is primarily nocturnal and omnivorous, juveniles observed feeding on mosquito larvae and fish, while adults consume snails, earthworms, prawns, fish, frogs, carrion, and vegetation. Animals maintained in captivity are known to eat rice and palm sugar sweetmeats. Courtship takes place underwater, and spherical, brittle-shelled, eggs in clutches numbering 20-30 are produced between August to November; hatching takes place between JuneJuly of the following year. The species is heavily exploited for its meat and calipee (the outer cartilaginous rim of the shell) throughout northern and eastern India and Bangladesh. The intensity of exploitation to which it is subject suggests that both some kind of quota or closed season system, as well as protection of nesting areas, are necessary.

Distribution. - Bangladesh, India, Nepal, Pakistan. Distributed across eastern Pakistan, northern, central, and eastern India, southern Nepal, and all of Bangladesh.

Synonymy. - Trionyx occellatus Gray 1830a, Trionyx ocellatus, Gymnopus ocellatus, Trionyx hurum Gray 1830b, Isola hurum, Aspideretes hurum, Aspidonectes hurum, Tyrse hurum, Amyda hurum, Nilssonia hurum, Gymnopus duvaucelii Duméril and Bibron 1835, Trionyx sewaare Gray 1872, Trionyx bellii Gray 1872, Trionyx buchanani Theobald 1874.

SubSPECIES. - None.

STATUS. - IUCN 2010 Red List: Vulnerable (A1cd+2d) (assessed 2000); CITES: Appendix I; Indian Wildlife (Protection) Act: Schedule I; Bangladesh Wildlife (Preservation) Act: Schedule III.

Taxonomy. - The first name proposed for this taxon was Trionyx occellatus Gray 1830a (Plate 78 in Illustrations of Indian Zoology; the specific epithet corrected later in the same work to Trionyx ocellatus), showing dorsal and ventral views of a juvenile. Webb (1980) showed that Trionyx ocellatus Gray 1830 is a primary (junior) homonym

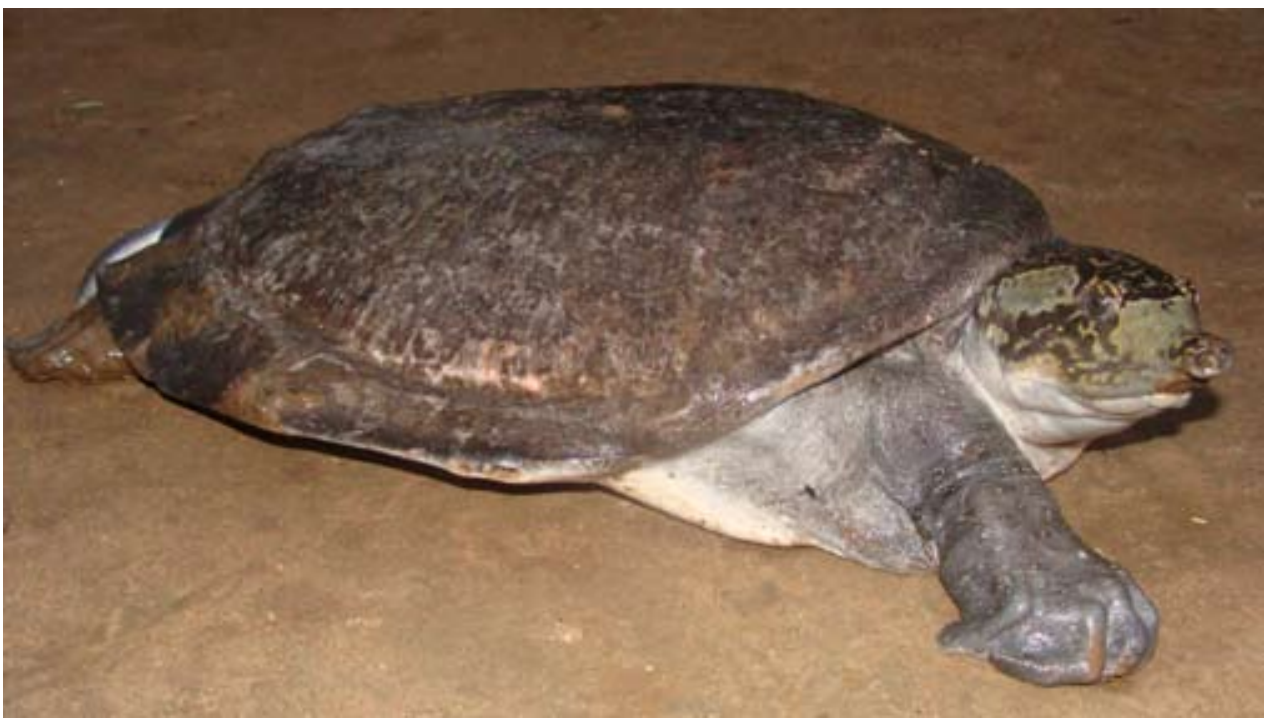

Figure 1. Adult female Nilssonia hurum from the Brahmaputra River, India. Photo by Chittaranjan Baruah. 


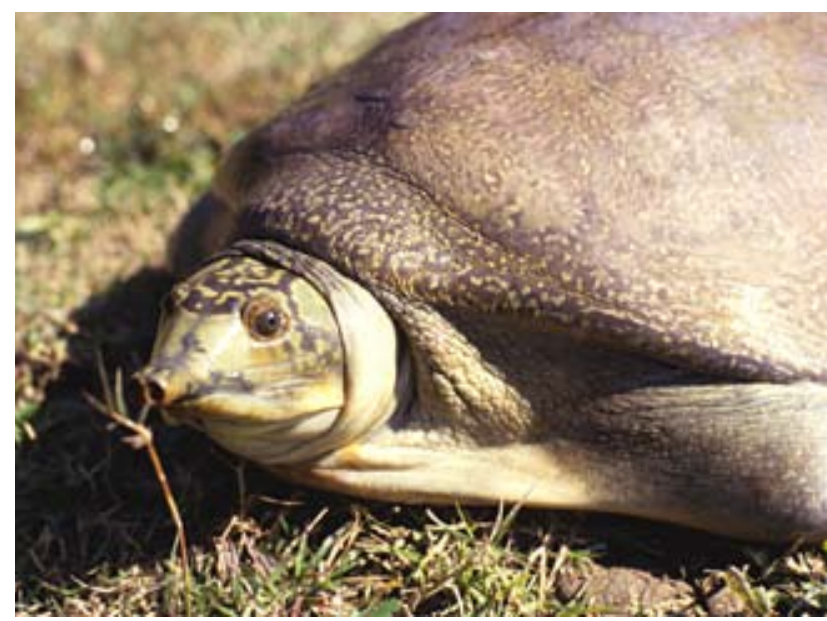

Figure 2. Adult Nilssonia hurum from Bangladesh. Photo by Indraneil Das.

of Trionyx ocellatus LeSueur 1827, a synonym of Apalone spinifera (LeSueur 1827), and thus not available. Trionyx hurum Gray $1830 \mathrm{~b}$ is the next available name, which was based on a manuscript name by the Scottish ichthyologist, Francis Hamilton (1762-1829), who later acquired the name Francis Buchanan (Theobald 1874), associated with Hamilton's drawings in the British Museum, originating from "Indiae fluvio Ganges", although the drawing bears the locality "Fatehgarh" $\left(27^{\circ} 22^{\prime} \mathrm{N}, 79^{\circ} 38^{\prime} \mathrm{E}, \mathrm{Uttar}\right.$ Pradesh, northern India), to which the type locality was restricted by Smith (1931). Webb (1980) emended the type locality to "Barrackpore (about $23 \mathrm{~km}$ north of Calcutta), West Bengal, India" (= Barakpur, 22 $\left.45^{\prime} \mathrm{N}, 8^{\circ} 20^{\prime} \mathrm{E}\right)$. Webb (1980) and Gemel and Praschag (2003) provided extensive discussions on the synonymy of Trionyx hurum, which includes Trionyx sewaare Gray 1872, Trionyx belli Gray 1872, and Trionyx buchanani Theobald 1874 . The species was transferred to the genus Aspideretes by Meylan (1987), along with three other species of large trionychids that were formerly in the trionychid genus Trionyx. More recently, Praschag et al. (2007) argued for an expanded concept of Nilssonia, and included the species of Aspideretes in it.

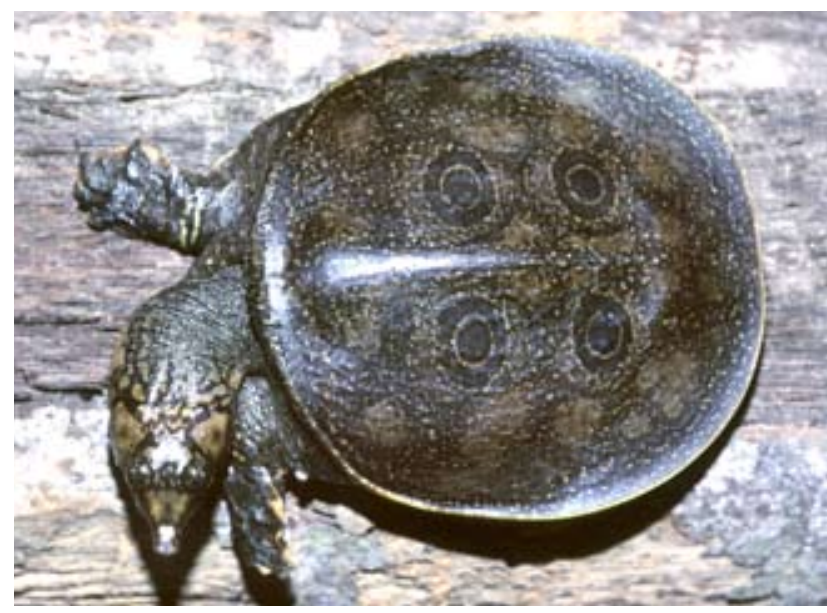

Figure 4. Juvenile Nilssonia hurum from Assam, India. Photo by Indraneil Das.

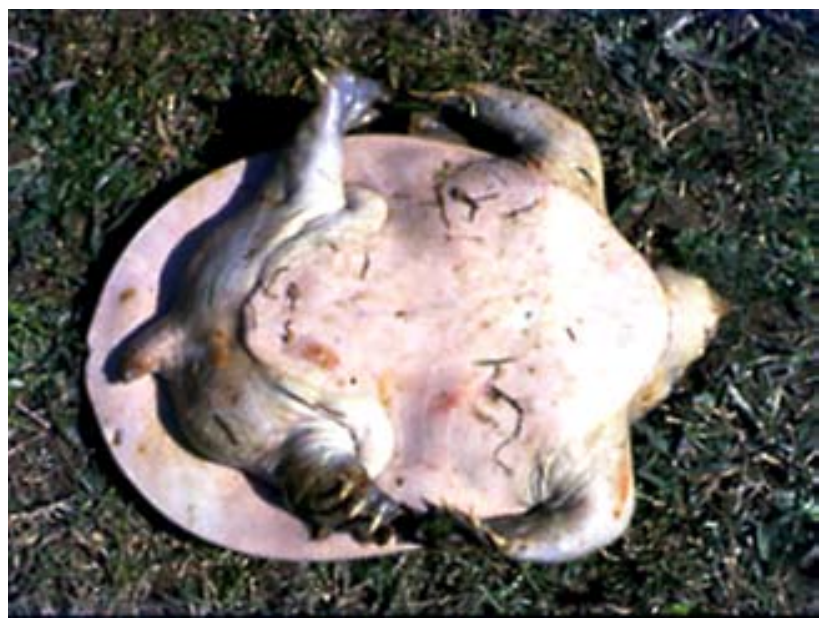

Figure 3. Adult Nilssonia hurum from India. Photo by Shailendra Singh.

Description. - The carapace is low and oval and the anterior edge has blunt tubercles. The head is large, and the snout is strongly downturned. A straight carapace length (bony disk plus leathery cartilaginous flap) of $60 \mathrm{~cm}$ is attained (Annandale 1912a).

The carapace is dark olive green to nearly black, sometimes with a yellow rim, and juveniles have 4 striking, orange ringed dark-centered ocelli, that are subequal and symmetrically positioned on an olive green carapace with dark reticulation; the eye-like markings becoming obscured with growth when the shell becomes darker. The plastron is dark in juveniles, turning light gray in adults. The head and limbs are olive green; the forehead has dark reticulations and large yellow or orange patches or spots, especially behind the eyes and across the snout, that are larger than those in its sister species, N.nigricans. These head markings are evident even in large individuals in which the carapacial pattern has been lost.

Males possess relatively longer and thicker tails than females, with the cloaca situated close to the tail-tip. No sexual dimorphism in shell color or patterns or size have been reported.

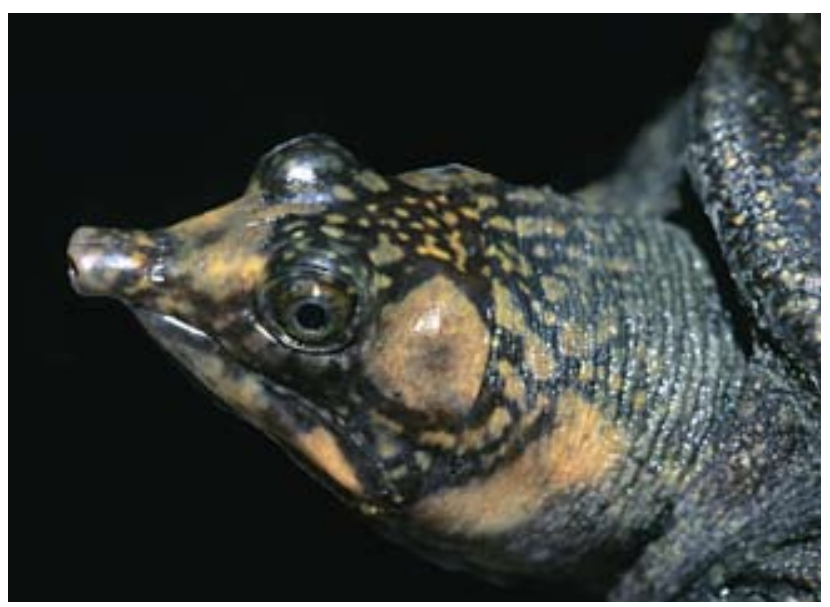

Figure 5. Juvenile Nilssonia hurum from Assam, India. Photo by Indraneil Das. 


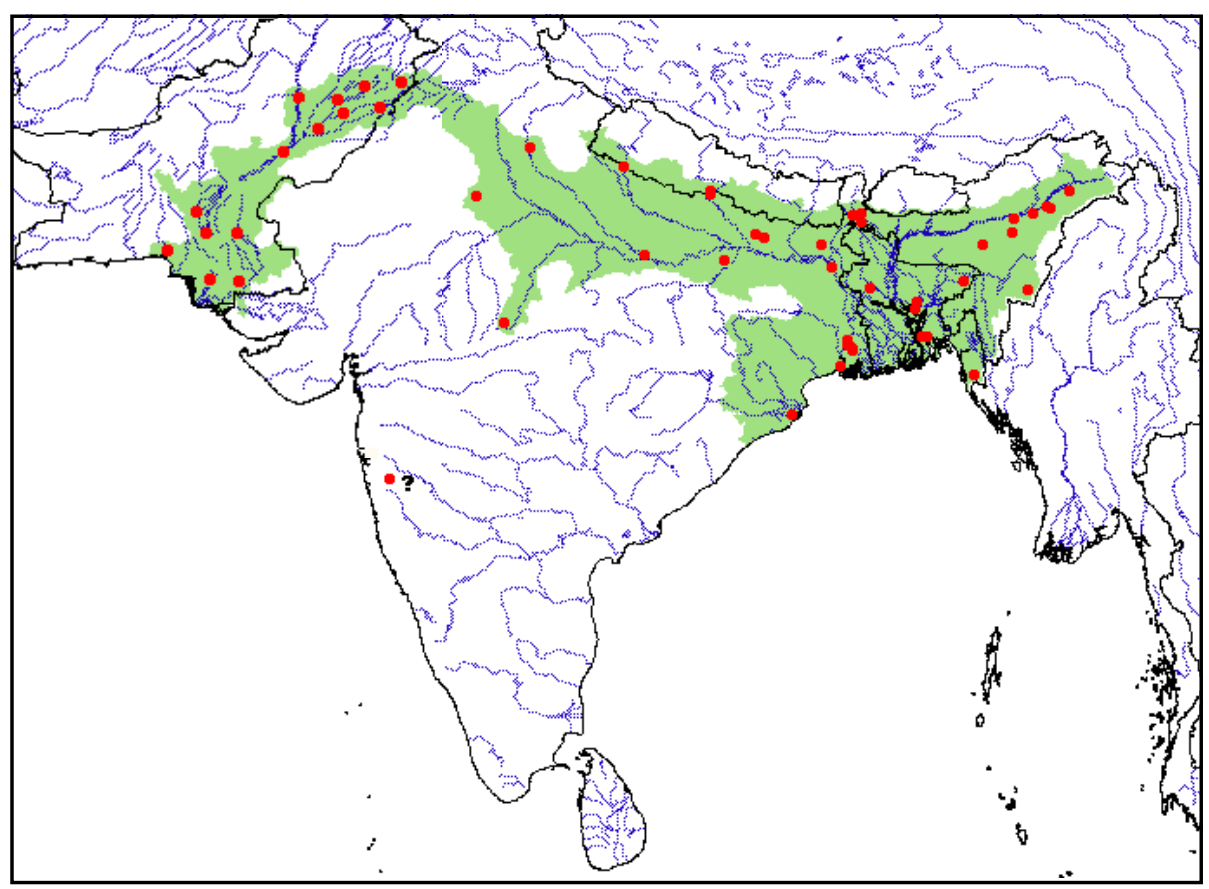

Figure 6. Distribution of Nilssonia hurum in Pakistan, India, and Bangladesh. Red points = museum and literature occurrence records based on Iverson (1992) plus more recent and authors' data; green shading = projected distribution based on GIS-defined hydrologic unit compartments (HUCs) constructed around verified localities and then adding HUCs that connect known point localities in the same watershed or physiographic region, and similar habitats and elevations as verified HUCs (Buhlmann et al. 2009), and adjusted based on authors' data. The question mark indicates the isolated questionable locality of Pune, Maharashtra.

The bony carapacial disk has eight pairs of costals and two (or sometimes three) neurals between the first pair of costals. The skull has ridgeless maxillary triturating surfaces with a median groove.

No subspecies have been described, although Rashid and Swingland (1997) suggested that the northern population differed from the southern one in color and snout shape.

The karyotype is unknown. Genetic work on the species has been conducted by Praschag et al. (2007), that allocate it to Nilssonia, and reveal a sister relationship with N.nigricans. Earlier, Engstrom et al. (2004) conduced a wider phylogeographic analysis of all extant species of Trionychidae, and revealed a relationship with the three South Asian species of large, softshell turtles (Nilssonia gangetica, $N$. nigricans, $N$. leithii), plus the Myanmar endemic ( $N$.formosa), which they retained in the clade Aspideretini Hay (1903).

Distribution. - The Indian peacock softshell turtle is widespread in the northern and central parts of the Indian subcontinent, but the southern and eastern limits of its distribution remain unclear. Verified examples have come from the tributaries of the rivers Indus, Ganga, Brahmaputra, and Subarnarekha, as well as their numerous tributaries (Smith 1931; Moll and Vijaya 1986), as well as from isolated bodies of water, sometimes far from major river drainages, for example:Puri,Orissa (Annandale 1912b); Pune, Maharashtra (Varghese and Tonapi 1986); Bhopal, Madhya Pradesh (Das 1987); Bharatpur, Rajasthan (Bhupathy and Ajith Kumar 1988); Misrik, Uttar Pradesh (Pai and Basu 1988); and Jiribam, Manipur (Singh 1995).

The record from Dohazari, south of Chittagong, in extreme southeastern Bangladesh (Das 1989), is of inter- est, and suggests that $N$. hurum might conceivably occur in western Myanmar as well, although that remains unverified, and the international border east of Chittagong corresponds to a mountain range that separates river systems in the two countries. Mertens (1969) reported a specimen from Pakistan, and this species has since been confirmed from the Indus drainage by Khan (2006), Noureen (2007), Noureen and Khan $(2007,2008)$, and Noureen et al. (2008). The records from Nepal are from the western, central, and Terai regions (Mitchell and Rhodin 1996; Schleich and Kästle 2002).

Old records of the species from Indo-China (Mocquard 1907), the Malay Peninsula (Flower 1899), and Borneo (de Rooij 1917), are based on erroneous identifications (see Annandale 1912a).

Habitat and Ecology. - The Indian peacock softshell turtle utilizes rivers, lakes, and ponds, from the upper reaches of the rivers, to the lowest, while apparently avoiding the saline river mouths. Its ability to burrow into the mud, while not as developed as that of Lissemys, may be associated with its ability to inhabit ponds and other lentic environments that may dry up during the dry season. Individuals were observed to surface every after 20-30 $\mathrm{min}$ in the Sarju River in the summer, comparatively more frequent than other sympatric softshelled turtle species such as $N$. gangetica or L. punctata. Adults were observed to utilize deeper sections of the river, while yearlings appears to stay in the shallower parts. Rashid and Swingland (1997) mentioned that the species migrates from drying ponds, and that is known to bask on the surface of water. The low abundance of this species in rivers like the Chambal in the western parts of its distribution may be due to the 
increasing gravelly nature of river beds, in comparison to the clayey beds of rivers in the eastern regions.

The species is reportedly primarily nocturnal (Noureen and Baruah 2010) and omnivorous; juveniles have been observed feeding on mosquito larvae and fish in captivity, and the stomach of a wild-collected adult in northern India contained fragments of snail shells (Das 1991). In Bangladesh, stomach samples contained earthworms (Pheretima posthuma), molluscs (Pila globosa), prawns, fish (including Amblypharyngodon mola, Mystus tengra, and Nandus nandus), frogs, as well as carrion and vegetable matter (Rashid and Swingland 1997; Schleich and Kaästle 2002). Khan (1987) reported the species to be omnivorous. Animals maintained at a temple tank in Puri, Orissa, eastern India, took rice and sweetmeats made of palm sugar (Annandale 1912b). Individuals maintained in the temple tanks and village ponds in Uttar Pradesh and Assam, India, were seen to feed on puffed rice, bread, and material generated as garbage as a result of religious activities (S. Singh, pers. obs.).

Flower's (1899) description of courtship in the species, reportedly underwater, with the males biting the females, and vocalizing, may refer to Amyda cartilaginea or an unknown turtle species, as Nilssonia hurum does not occur in southeast Asia.

In Bangladesh, nests are 10-30 $\mathrm{m}$ away from the edge of water, and 15-25 cm deep; the spherical, ca. $30 \mathrm{~mm}$ in diameter, brittle-shelled eggs, numbering 20-30 eggs in a clutch are produced during the winter months, and there is evidence of multiple clutching in Bangladesh (Rashid and Swingland 1997). Nesting of N. hurum in the Chambal occurs along with that of $N$. gangetica in the months of August to November, and hatching takes place in June-July of the following year. Clutch range in the Chambal is 10-30, with a mean of 18 (D. Basu, pers. obs.). Hatchling takes place just before the main monsoons (mid-June to mid-July) on the Sarju River, in the north Indian Terai (foothills of the Himalayas). One recently hatched nest was examined from a dried-up nulllah (stream) adjacent to the Sarju River. The mean carapace length of three hatchlings was $46 \mathrm{~mm}$.

The trematode parasite, Cephalogonimus mukerjius is known to infect this turtle (Rai 1961).

Population Status. - No information on population sizes is available. This appears to be the most common large softshell turtle in the lower parts of the Ganges system; however, in the central and upper regions the species appears to be outnumbered by $N$. gangetica. In the Chambal River, $N$. hurum nests comprised $<2 \%$ of $N$. gangetica nests (D. Basu, unpubl. data). The species was fairly abundant in slow-flowing rivers and wetlands in the Terai of northern India, but populations seem to be declining due to commercial exploitation and habitat alteration. The notable north Indian habitats, where large populations of the species have recently been recorded, are Sarju, Kane, and Rapti rivers, and a few oxbow lakes in the area (S. Singh, pers. obs.). In Azam and Randhawa's (2008) study site in Pakistan's Punjab Province (at Head Punjnad and Head Trimmu), N. hurum was the most abundant turtle species (after Pangshura smithii), and was described as "plentiful" in "shallow muddy ditches, lakes and marshes". In another study in the same province of Pakistan, Akbar et al. (2006) described the species as frequently encountered. In Bangladesh, this appears to be the most abundant large softshell turtle (Rashid and Swingland 1997), although the concept of $N$. hurum at the time also included the often sympatric and morphologically similar N. nigricans.

Threats to Survival. - Annandale (1912a) reported a consignment of over 500 individuals from Khulna, currently in Bangladesh, in the early 1900s, mentioning that the trade was restricted to the month of October. Based on market surveys conducted in the early 1980s, Moll (1983) found the species to be the third most commonly exploited turtle in eastern India, after L. punctata and N. gangetica. Threats in the River Ganga to the species are those generic for all large river turtles, including reduction of fish stock, as a result of overfishing, pollution, increase in river traffic, and sand-mining, among others (Rao 2001).

The species is extensively hunted in all of northern and eastern India for its meat and calipee (the outer cartilaginous rim of the shell), which is extracted from live turtles by removing up to ca. $10 \mathrm{~cm}$ of the rim from limb to limb. The calipee is dried and sold along with that of sympatric species such as $N$. gangetica and Chitra indica. The calipee commands a higher price (due to low fat content) in comparison to that of the Indian narrow-headed softshell, Chitra indica, and one kilo of dried calipee fetching fishermen 1700 Indian Rupees (ca. US\$22) from middlemen. It is probable that the final destinations are the markets of China and/or Southeast Asia, via Bangladesh, where it is used in cuisine and Traditional Chinese Medicine (TCM). A single animal of $30 \mathrm{~kg}$ can produce about $650 \mathrm{~g}$ of dried calipee. In the state of Uttar Pradesh, turtlers typically locate the species using an iron probe during the dry season, baited and unbaited "thousand hook" lines before and after the monsoons, and fall and set nylon nets during the winter. In the state of Uttar Pradesh, the species was recorded in five of 11 live and dead consignments (comprising over 500 turtles of different species) seized by the Uttar Pradesh Police Department in 2009. Noureen and Baruah (2010) reported that in the first week of November, large numbers of eggs of this species are excavated from islands on the Brahmaputra, for local consumption or sale.

In Bangladesh, $N$. hurum is the most heavily exploited species, most animals caught ending up in markets in Southeast Asia (Das 1990; Rashid and Swingland 1990). Export peaked between the mid-1980s and early 1990s, when ca. 10,000 metric tonnes of the species were exported annually (Rashid and Khan 2000). Fugler (1984) noted that in Bangladesh, these turtles are caught with hooks fixed to short cords, which are attached at intervals of about half a meter to a 60-600 m cord, and baited with offal, mussel, shrimp or fish.

In Pakistan, the species is exploited for export to China, both as meat and calipee (Noureen and Khan 2007, 2008; Noureen et al., 2008); other local threats being incidental 
capture in fishing gear, canal closure, and desiltation of water bodies (Akbar et al . 2006). Trade reports for China (Zhang et al. 2008) confirm the importation of this turtle for use in the food and indigenous medicine trade. In Nepal, the species is reportedly used for food and medicine (Shah and Tiwari 2004).

Conservation Measures Taken. - The species is listed under Appendix I of CITES, Schedule I of the Indian Wildlife (Protection) Act 1972,Appendix III of the Wildlife Protection Ordinance for Sindh, Punjab, Balochistan, and Northwest Frontier Agency (all in Pakistan), and Schedule III of the Bangladesh Wildlife (Preservation) Act of 1974. Its export from Pakistan has been banned by the Pakistan Export Policy, 2006-2007. Nonetheless, continuing illegal export to China for TCM, especially from Bangladesh and Pakistan, appears to occur frequently (Rashid and Khan 2000; Noureen and Khan 2007, 2008; Noureen et al. 2008). The species is included in the Red Data Book for Nepal (Shah and Tiwari 2004). The IUCN Red List categorizes the species as Vulnerable (www.iucnredlist.org).

This species occurs in several protected areas within its natural range, including the Pakhui Wildlife Sanctuary (Arunachal Pradesh), Mupa-Lanteng Reserve Forest (Assam), Bherihari Wildlife Sanctuary (Bihar), Hastinapur Wildlife Sanctuary (Uttar Pradesh), Sarnath Turtle Sanctuary (Uttar Pradesh), the NationalChambal Sanctuary (Madhya Pradesh and Rajasthan), and Keoladeo National Park (Rajasthan) in India and the Sunderban Wildlife Sanctuaries (comprising East, West and South sectors) of Bangladesh. Some efforts to restore the heavily polluted River Ganga via pollution control have begun in the past decade (Rao 2001).

Conservation Measures Proposed. - Trade in the species may be difficult to stop in the short-term, and the protection of nesting grounds, especially during the breeding season, and other critical habitats of the species, in addition to better enforcement, especially addressing transborder trade, may be a more suitable strategy. Thus, better enforcement and partial amendments of the existing laws may be warranted, to allow some sustainable utilization of this large, commercially valuable species. These include annual quotas on numbers removed or a closed season system, as well as protection of nesting areas. The turtle hunters may need to be rehabilitated through encouragement to opt for more river-friendly livelihoods, rather than catching turtles for middlemen for nominal monetary gains

Captive Husbandry. - Annandale (1912b) reported a population of this species in captivity at a temple in Puri, Orissa State, eastern India, but P.C.H. Pritchard reported in the 1980 s (pers. comm.) that this captive colony appears to have died out. Juveniles maintained in captivity ate fishes and mosquito larvae (I.Das, pers.obs.). Varghese and Tonapi (1986) classified the species as carnivorous, reporting annelids, molluscs, arthropods, fish fingerlings, and tadpoles in its diet in captivity. These authors also reported that while macrophytes are generally avoided, floating root-tips of plants are ingested when starved for 1-2 weeks. Animals kept in temple ponds in eastern India feed on offerings from pilgrims, including cakes, fruits, animal viscera and rice (Noureen and Baruah 2010). Such animals are vulnerable to both inbreeding, aggression as a result of high stocking densities, and fungal attack. One large die-off in August 2008, involving about 13 turtles at the Madhab Temple at Hajo, Assam, in eastern India was reported by Noureen and Baruah (2010).

Current Research. - The reproductive biology and scale of trade of the species is being studied by Shailendra Singh, supported by the Turtle Survival Alliance, in northern India.

Acknowledgments. - Supported by the Centre for Herpetology, Madras Crocodile Bank Trust, Universiti Malaysia Sarawak, and the Katerniaghat Foundation. The Turtle Survival Alliance is thanked for the current species initiative. John Iverson offered helpful comments on a draft. We thank Chittaranjan Baruah for contributing the photo in Fig. 1.

\section{LITERATURE CITED}

Akbar, M., Mushtaq-ul-Hassan, M. and Zaib-u-Nisa. 2006. Distribution of freshwater turtles in Punjab, Pakistan. Caspian Journal of Environmental Sciences 4:142-146.

Annandale, N. 1912a. The Indian mud-turtles (Trionychidae). Records of the Indian Museum 7:151-179.

AnNANDALE, N. 1912b. The aquatic Chelonia of the Mahanaddi and its tributaries. Records of the Indian Museum 7:261-266.

AZAm,M.M. andRandHawa,A.A.2008. Studies on WildlifeDiversity of Two Wetlands With Particular Reference to Freshwater Turtles. Islamabad: Zoological Survey Department, 20 pp.

Buhlmann, K.A., Akre, T.S.B., Iverson, J.B., Karapatakis, D., MitTERMEIER, R.A., Georges, A., Rhodin, A.G.J., van DiJK, P.P., AND GibBons, J.W. 2009. A global analysis of tortoise and freshwater turtle distributions with identification of priority conservation areas. Chelonian Conservation and Biology 8(2):116-149.

Bнupathy, S. and Алтth Kumar, C.R. 1988. On the identity and occurrence of the peacock soft shell (Trionyx hurum) in Rajasthan. Journal of the Bombay Natural History Society 85:624.

DAS, I. 1987. New locality record for the Indian peacock softshell turtle Trionyx hurum. Journal of the Bombay Natural History Society 84:691-692.

DAs. 1989. Report of a survey of freshwater turtles and land tortoises in Bangladesh. Report to the Fauna and Flora Preservation Society, London, $10 \mathrm{pp}$.

DAs, I. 1990. The trade in freshwater turtles from Bangladesh. Oryx 24:163-166.

DAS, I. 1991. Colour Guide to the Turtles and Tortoises of the Indian Subcontinent. Portishead: R \& A Publishing, 133 pp.

DERooIs,N. 1915. The Reptiles of the Indo-AustralianArchipelago. Vol. I. Lacertilia, Chelonia, Emydosauria. Leiden: E.J. Brill, 384 pp.

Engstrom, T.N., ShafFer, H.B., AND McCord, W.P. 2004. Multiple data sets, high homoplasy, and the phylogeny of softshell turtles (Testudines: Trionychidae). Systematic Biology 53:693-710.

FLOWER, S.S. 1899. Notes on a second collection of reptiles made in the Malay Peninsula and Siam, from November 1896 to September 1898 , with a list of species recorded in these countries. Proceedings of the Zoological Society of London 1899:600-696.

FugLeR, C.M. 1984. The commercially exploited Chelonia of Bangladesh: taxonomy, ecology, reproductive biology, and ontogeny. Bangladesh Fisheries Information Bulletin 2(1):1-52. 
GEMEL,R.ANDPRASCHAG,P.2003.On the nomenclature and vernacular names of recent Aspideretes species (Reptilia, Testudines, Trionychidae). Zoologische Abhandlungen, Dresden 53:93-105.

GrAY, J.E. 1830a. Illustrations of Indian Zoology, chiefly selected from the collection of Major-General Hardwicke. Vol. I, Part 4, pls. 75, 78. London: Treuttel, Wurtz, Treuttel, Jun. and Richter.

Gray, J.E. 1830b. A Synopsis of the Species of the Class Reptilia. In: Griffith E. and Pidgeon, E. The Class Reptilia arranged by the Baron Cuvier, with specific descriptions.In: Griffith,E.(Ed.). The Animal Kingdom Arranged in Conformity with its Organization, by the Baron Cuvier, with Additional Descriptions of all the Species Hitherto Named, and of many not before Noticed. Vol.9. Reptilia. Supplement. London: Whittaker, Treacher, and Co., 110 pp.

GraY, J.E. 1872. Notes on the mud-tortoises of India (Trionyx, Geoffroy). Annals and Magazine of Natural History (4)10:326-340.

HAY, O.P. 1903. On the existing genera of the Trionychidae. Proceedings of the American Philosophical Society 42:268-274.

Iverson, J.B. 1992. A Revised Checklist with Distribution Maps of the Turtles of the World. Richmond, IN: Privately published, $363 \mathrm{pp}$.

KHAN, M.A.R. 1987. Bangladesher Bonnyoprani. Vol. I. Urochor o Shorishrip. Dhaka: Bangla Academy, 169 pp.

KHAN, M.S. 2006. Amphibians and Reptiles of Pakistan. Malabar, FL: Krieger Publishing Company, 311 pp.

LeSueur, C.A. 1827. Notes sur deux espèces de tortues du genre Trionyx Geoffroy-Saint Hillaire. Mémoirs du Muséum d'Histoire Naturelle de Paris 15:257-268.

Mertens, R. 1969. Die Amphibien und Reptilien West-Pakistans. Stuttgarter Beiträge zur Naturkunde 197:1-96.

MeYLan, P.A. 1987. The phylogenetic relationships of soft-shelled turtles (Family Trionychidae). Bulletin of the American Museum of Natural History 186:1-101.

Mitchell, J.C. AND Rhodin, A.G.J. 1996. Observations on the natural history and exploitation of the turtles of Nepal, with life history notes on Melanochelys trijuga. Chelonian Conservation and Biology 2:66-72.

MocQuard,F. 1907.Les reptiles de l'Indochine.La Revue Coloniale, Paris 1907:5-59.

Moll, E.O. 1983. A status survey of freshwater turtle resources in India (September 1982 - June 1983) with recommendations for management. New Delhi: Report to the American Institute for Indian Studies, $26 \mathrm{pp}$.

NoureEn, U. 2007. A preliminary visit to Dera Ismail Khan to assess the status of freshwater turtles of Pakistan. Report to the Ministry of Environment, Pakistan Wetlands Programme, 23 pp.

Noureen, U. AND BARUAH, C. 2010. Le Trionyx à ocelles Nilssonia hurum (Gray, 1831) (Ang: Indian peacock softshell turtle). Chéloniens 18:39-45.

Noureen, U. AND Khan, A. 2007. Freshwater turtles of Pakistan: a preliminary assessment of their status in Punjab and Sindh. Report to the Ministry of Environment's Pakistan Wetlands Programme, Islamabad, $23 \mathrm{pp}$.

NoureEn, U. AND KHAN, A. 2008. Conservation of freshwater turtles in Pakistan. TRAFFIC Bulletin 21(3):99-100.

Noureen,U.,BrauliK,T.G.,Arshad,M., AND Khan,H.N.2008.Illegal trade in freshwater turtle parts: preliminary findings of turtle trade in major barrages and head-works of Punjab. Report to the Ministry of Environment's Pakistan Wetlands Programme, 28 pp.

PAI, A. AND BASU, D. 1988. Turtles of an ancient pilgrimage tank in north India with notes on the distribution of the peacock soft-shell turtle (Trionyx hurum). Hamadryad 13:12-15.
Praschag, P. and Gemel, R. 2002. Identity of the black soft-shell turtle Aspideretes nigricans (Anderson, 1875), with remarks on related species (Reptilia: Testudines: Trionychidae). Faunistische Abhandlungen Staatliches Museum für Tierkunde Dresden 23(5):87-116.

Praschag, P., Hundsdörfer, A.K., Reza, A.H.M.A, and Fritz, U. 2007. Genetic evidence for wild-living Aspideretes nigricans and a molecular phylogeny of south Asian softshell turtles (Reptilia: Trionychidae: Aspideretes, Nilssonia). Zoologica Scripta 36:301-310.

RAI, S.L. 1961. On a new trematode Cephalogonimus mukerjius $\mathrm{n}$. sp. of the genus Cephalogonimus Poirier, 1886, from the intestine of Trionyx hurum. Indian Journal of Helminthology 13:79-92.

RAO, R.J. 2001. Biological resources of the Ganga River, India. Hydrobiologia 458:159-168.

RASHID, S.M.A. AND KHAN, S.M.H. 2000. Overview of turtle trade in Cambodia.In: vanDijk,P.P.,Stuart,B.L., and Rhodin,A.G.J.(Eds.). Asian Turtle Trade: Proceedings of a Workshop on Conservation and Trade in Freshwater Turtles and Tortoises in Asia. Chelonian Conservation Monographs 2:77-85.

RASHID, S.M.A. AND Swingland, I.R. 1990. Interim report on the freshwater turtle trade in Bangladesh. Asiatic Herpetological Research 3:123-128.

RASHID, S.M.A. AND SwINGLAND, I.R. 1997. On the ecology of some freshwater turtles in Bangladesh. In: Van Abbema, J. (Ed.). Proceedings: Conservation, Restoration, and Management of Tortoises and Turtles - An International Conference. New York: New York Turtle and Tortoise Society, pp. 225-242.

SHAH, K.B. AND TIWARI, S. 2004. Herpetofauna of Nepal.AConservation Companion. Kathmandu: IUCN Nepal, 237 pp.

Schleich, H.H. AND KästLE, W. 2002. Order Chelonia/Testudines (turtles: terrapins and tortoises). In: Schleich,H.H. and Kästle, W. (Eds.). Amphibians and Reptiles of Nepal. Biology, Systematics, Field Guide. Königstein: Koeltz Scientific Books, pp. 501-573.

SingH, K. S. 1995. On a collection of reptiles and amphibians of Manipur. Geobios News Reports 14:135-145.

Theobald, W. 1874. Observations on some Indian and Burmese species of Trionyx. Proceedings of the Asiatic Society of Bengal 1874:75-87.

VARGHESE, G. AND TonAPI, G.T. 1986. Observations on the identity of some Indian freshwater turtles and their feeding habits. Biological Conservation 37:87-92.

Weвв, R.G. 1980. Gray,Hardwicke,Buchanan-Hamilton, and drawings of Indian softshell turtles (Family Trionychidae). AmphibiaReptilia 1:61-74.

Zhang, L., HuA N., AND Sun, S. 2008. Wildlife trade, consumption and conservation awareness in southwest China. Biodiversity and Conservation 17:1493-1516.

\section{Citation Format for this Account:}

Das, I., Basu, D., AND Singh, S. 2010. Nilssonia hurum (Gray 1830) - Indian peacock softshell turtle. In: Rhodin, A.G.J., Pritchard, P.C.H., van Dijk, P.P., Saumure, R.A., Buhlmann, K.A., Iverson, J.B., and Mittermeier, R.A. (Eds.). Conservation Biology of Freshwater Turtles and Tortoises: A Compilation Project of the IUCN/SSC Tortoise and Freshwater Turtle Specialist Group. Chelonian Research Monographs No. 5, pp. 048.1-048.6, doi:10.3854/crm.5.048.hurum.v1.2010, http:// www.iucn-tftsg.org/cbftt/. 